\title{
The journey of success: from an idea to a journal
}

\author{
Tauseef Ahmad*
}

Department of Epidemiology and Health Statistics, School of Public Health, Southeast University, Nanjing (210009), China

\section{Correspondence}

Tauseef Ahmad, Department of Epidemiology and Health Statistics, School of Public Health, Southeast University, Nanjing (210009), China

Email: Tauseef.ahmad@hu.edu.pk

History

- Received: 1 September 2018

- Accepted: 6 September 2018

- Published: 21 September 2018

DOI : 10.15419/bmrat.v5i9.472

\section{Check for updates}

\section{Copyright}

(C) Biomedpress. This is an openaccess article distributed under the terms of the Creative Commons Attribution 4.0 International license.

\section{Dear Sir,}

From the beginning of life on this planet research and writing remained one of the most important aspect for getting more attentions and values. But, with the passage of times different methods has been introduced to share the knowledge and information i.e. from hand writing to hard publication and then to online publication.

Dear readers, it was a story of 2015 when the honorable Dr. Phuc Van Pham (Founder and Editor-inChief) came with an idea and started the journal with name Biomedical Research and Therapy is the official journal of the Laboratory of Stem Cell Research and Application (SCL) ${ }^{1}$ (now as Stem Cell Institute, VNUHCM University of Science, Ho Chi Minh city, Viet Nam). After launching the journal, it was thinking that the journal will not exist for long time, because it was a hard journey with limited resources. However, the journal is entered in to their $5^{\text {th }}$ volume in 2018. Due to the hard working, creative ideas, team working and non-stoppable efforts of Dr. Pham and his team proofed that Biomedical Research and Therapy is one the emerging journal in the field of biomed- ical sciences.

The journal is now indexed and abstracted by world renowned databases including Web of Science, Scopus, Embase, Index Copernicus, Ebsco, and Google Scholar. In a very short time of period the journal become more popular in the Asian countries. Researchers from different parts of the world is publishing their work in Biomedical Research and Therapy. On the behalf of Editor-in-Chief and Editorial Office of Biomedical Research and Therapy I am thankful and extended my gratitude to every single person who contributed for this journal. We also acknowledge the support of Springer International Publisher. I do hope that all of you will continue your valuable and non-stoppable support for Biomedical Research and Therapy.

Tauseef Ahmad

Associate Editor, Biomedical Research and Therapy

\section{REFERENCES}

1. Pham PV. Welcome to Biomedical Research and Therapy. Biomedical Research and Therapy. 2014;1(01):1-1.

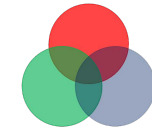

